\title{
The Effects of Proteins on Bacterial Attachment to Polystyrene
}

\author{
By MADILYN FLETCHER \\ Marine Science Laboratories, University College of North Wales, \\ Menai Bridge, Gwynedd LL59 $5 E H$
}

(Received 21 August 1975; revised 30 October 1975)

SUMMARY

Bovine serum albumin, gelatin, fibrinogen and pepsin impaired the attachment of a marine pseudomonad to polystyrene Petri dishes, apparently through adsorption on the dish surface. Serum albumin also appeared to affect the bacterial surface. The basic proteins protamine and histone did not markedly inhibit attachment. These findings are discussed in relation to comparative experiments using tissue cells.

\section{INTRODUCTION}

Many bacteria in natural waters and biological fluids are able to attach to available surfaces and proliferate (Corpe, 1970; Newman, 1974), and there appears to be some relationship between this attachment process and the concentration of dissolved organic material in the medium. There have been several suggestions that when the organic nutrient concentration is very low, bacteria can grow more readily after having attached to available surfaces (ZoBell \& Anderson, 1936; Lloyd, 1937; Heukelekian \& Heller, 1940; ZoBell, 1943), presumably because adsorbed nutrients are concentrated and thus more accessible. The addition of certain proteins (Meadows, 197I ; Fletcher, 1974) or glucose (Marshall, Stout \& Mitchell, 1971) to the medium can increase or reduce bacterial attachment. This paper describes an investigation into the effects of selected proteins on the adhesion of a marine pseudomonad to polystyrene.

\section{METHODS}

Organism. The bacterium, a marine isolate, was identified as a Pseudomonas sp., group I, according to the scheme of Shewan, Hobbs \& Hodgkiss (1960). It is a motile rod with a single polar flagellum, is oxidase positive (Kovács, I956), oxidizes but does not ferment glucose (Hugh \& Leifson, 1953) and produces a weakly fluorescent, diffusable pigment in medium B of King, Ward \& Raney (I954).

Preparation of bacterial suspensions. The medium comprised $0.1 \%(\mathrm{w} / \mathrm{v})$ peptone (Oxoid) and $0.1 \%(\mathrm{w} / \mathrm{v}$ ) yeast extract (Oxoid) in filtered (porosity $0.2 \mu \mathrm{m}$ ) seawater, $\mathrm{pH} 7 \cdot 6$. Portions $(250 \mathrm{ml})$ of the medium were inoculated with $2 \mathrm{ml}$ from a stationary-phase culture and incubated for $24 \mathrm{~h}$ at $18{ }^{\circ} \mathrm{C}$, with aeration by bubbling. At the end of the incubation period, the organisms were in the late-exponential or early-stationary growth phase.

Control preparations: attachment. The bacterial suspensions were pooled, and the organisms from $150 \mathrm{ml}$ portions were collected by centrifugation and resuspended in $100 \mathrm{ml}$ seawater, which had been filtered (as above) and autoclaved. The extinction of the suspension was measured and calibrated against total cell count. Portions $(30 \mathrm{ml})$ of the suspension were transferred to polystyrene Petri dishes (Sterilin), and the bacteria were allowed to attach to the dish surface for $2 \mathrm{~h}$ at 18 to $20^{\circ} \mathrm{C}$.

Protein treatments. The proteins tested were selected to include a wide range of isoelectric 
points (taken from Florkin \& Stotz, 1963): bovine serum albumin, fraction V (BDH; pI 4.7, 4.9); gelatin (type I, Sigma; pl 4.7, 5.0); fibrinogen, bovine (type I, Sigma; pl 5.5, $5 \cdot 8$ ); pepsin, I : 60000 (Sigma; pI I.0); protamine sulphate (grade I, Sigma; pI I 2.4); histone (type Il, Sigma; pI 10.8). Suspensions were treated as described under Control preparations, with the following modifications:

(i) Attachment in the presence of dissolved protein. After centrifugation, the bacteria were resuspended in sterile filtered seawater containing either $\sim 0.2 \%$ (w/v) pepsin or $\sim 0.5 \%(\mathrm{w} / \mathrm{v})$ serum albumin, gelatin, fibrinogen or protamine. Pepsin had no enzymic action, since it is active only in acid solution.

(ii) Treatment of bacteria with protein before attachment. Before the bacteria were centrifuged, 5 or $10 \mathrm{ml}$ of protein solution were added to the culture to give a final concentration of $\sim 0.2 \%(\mathrm{w} / \mathrm{v})$ fibrinogen or pepsin or $\sim 0.5 \%(\mathrm{w} / \mathrm{v})$ serum albumin, gelatin or protamine. This was incubated for $30 \mathrm{~min}$ at $\mathrm{I} 8$ to $20^{\circ} \mathrm{C}$ before collecting the bacteria. Histone was not used in treatments (i) and (ii) because it was insoluble in the slightly alkaline medium.

(iii) Attachment of bacteria to protein-coated polystyrene Petri dishes. Protein films were adsorbed on to Petri dish surfaces by filling each dish with a sterile $0.1 \%$ (w/v) solution of the protein in filtered seawater. Histone was dissolved in acidified seawater. After 2 to $3 \mathrm{~h}$, the solution was poured off and the dish gently rinsed four times with sterile filtered seawater. Bacterial suspensions were added immediately. All proteins, except protamine and histone, left the dish surface completely wettable, indicating the formation of an adsorbed film.

(iv) Attachment of bacteria to protein-coated tissue culture dishes. Procedure (iii) was followed, except that polystyrene tissue culture dishes (Sterilin) were used, and only gelatin, pepsin and protamine were tested. Each treatment was done in duplicate; (i), (ii) and (iii) were repeated at least once.

Preparation of plates for measurement of bacterial attachment. After the attachment period, the bacterial suspensions were poured off, and each dish was rinsed four times with sterile distilled water to remove any loosely adsorbed organisms which had not actually attached (cf. Marshall et al., 197I). The same experimental results were obtained whether distilled, tap or seawater was used for rinsing. The bacteria left adhering to the dish were fixed with Bouin's fixative and stained with ammonium oxalate-crystal violet, and the dishes were left inverted to air-dry. The fixation and staining procedures did not influence the number of bacteria found attached to the polystyrene surface.

The number of attached bacteria was determined indirectly by measuring the extinction of the stained bacterial film against clean polystyrene at $590 \mathrm{~nm}$ (the absorption maximum of crystal violet). Four separate readings were made for each Petri dish. This method of measurement was valid because of the even distribution of the bacteria and the large number of attached organisms in the control preparations. It also dispensed with tedious and timeconsuming counting of individual bacteria.

\section{RESULTS}

The relationship between the number of bacteria attached and the initial culture concentration

The culture concentrations ranged between $2.5 \times 10^{9}$ and $5 \times 10^{9}$ bacteria/ml, and the extinction measurements of stained bacterial films on control Petri dishes ranged between 0.33 and 0.44 . Within these ranges, however, there was no strict correlation between bacterial concentration and the extinction of the film subsequently formed. 
Table I. The effects of proteins on attachment of bacteria to polystyrene Petri dishes

Attachment was assessed by measuring the mean extinction of attached bacteria which had been fixed and stained as described in Methods. Measurements were made of bacteria which attached (i) in the presence of dissolved protein, (ii) after pretreatment with protein, and (iii) after coating the Petri dishes with protein (see Methods for details). Control dishes not treated with protein were prepared as described in Methods, and their mean extinction was $0.38 \pm 0.04$ (S.D.). Mean values for duplicate samples are given.

\begin{tabular}{lccc}
\multirow{2}{*}{$\begin{array}{c}c \\
\text { Protein }\end{array}$} & $\overbrace{\text { (i) }}$ of attached bacteria \\
Serum albumin & 0.02 & (ii) & (iii) \\
\multirow{3}{*}{ Gelatin } & 0.14 & 0.13 \\
& 0.08 & 0.20 & 0.07 \\
Fibrinogen & 0.04 & 0.32 & 0.16 \\
& 0.13 & 0.37 & 0.10 \\
Pepsin & 0.09 & 0.46 & 0.10 \\
& & & 0.26 \\
Protamine & 0.01 & 0.37 & 0.27 \\
\multirow{2}{*}{ Histone } & 0.03 & 0.45 & 0.15 \\
& 0.18 & 0.31 & 0.37 \\
& 0.28 & 0.36 & 0.38 \\
& - & - & 0.28 \\
& - & - & 0.42
\end{tabular}

Table 2. Attachment of bacteria to protein-coated polystyrene tissue culture dishes

\begin{tabular}{lcc} 
& $E_{590}$ of attached bacteria \\
\cline { 2 - 3 } Protein & $\overbrace{\text { Control dishes }}$ & Experimental dishes \\
Gelatin & 0.09 & 0.01 \\
Pepsin & 0.19 & 0.00 \\
Protamine & 0.19 & 0.14
\end{tabular}

The effects of proteins on bacterial attachment to Petri dishes

Table I gives the mean extinction measurements for bacteria attached to polystyrene Petri dishes. From the data, the following points should be noted:

(i) The proteins which markedly inhibited attachment when present in the bacterial culture during the attachment period (serum albumin, gelatin, fibrinogen, pepsin) also inhibited attachment when present as an adsorbed film on the Petri dish surface.

(ii) The only protein to inhibit adhesion through action on the bacteria was bovine serum albumin.

(iii) Only the basic proteins, protamine and histone, had no effect through adsorption on to the Petri dish surface.

The attachment of bacteria to tissue culture dishes with adsorbed protein films

Table 2 gives the mean extinction measurements for bacteria attached to tissue culture dishes. Very few bacteria attached to the control dishes, and even fewer attached to dishes coated with gelatin or pepsin. Protamine had no significant effect.

\section{DISCUSSION}

To inhibit bacterial attachment, dissolved protein must be able to affect at least one of the three components of the attachment mechanism - the bacterial surface, the attachment sur- 
face or the surrounding medium. The influence of protein on the medium is probably not significant in these experiments since the most pertinent change in the medium resulting from an increase in dissolved protein is an increase in fluid viscosity (cf. Curtis, I962), and no direct relationship between viscosity and attachment inhibition could be detected (Fletcher, unpublished results). Also, the importance of medium viscosity is reduced when the cells are motile (Weiss, I964).

Only one of the proteins tested, bovine serum albumin (BSA), appeared to prevent attachment through action on the bacterial surface (Table $I$, ii). This effect is unexplained, but probably resulted from adsorption on, or reaction with, the bacterial extracellular adhesive (cf. Fletcher \& Floodgate, I973), and may be related to the high number of nonpolar side chains of BSA, as compared with the other proteins tested (Fruton \& Simmonds, 1958).

The proteins BSA, gelatin, fibrinogen and pepsin appeared to inhibit bacterial adhesion through adsorption on the attachment surface (Table I,iii). Adsorbed proteins may make a surface less suitable for attachment either by modifying the ionic micro-environment of the surface (Brooks \& Seamann, 1973) or by forming a macromolecular 'scaffolding' to which the bacteria are unable to adhere (Maroudas, 1973, 1975a). It is well established that adsorbed proteins can influence the attachment of tissue culture cells to the underlying substratum. In contrast to the results reported here, most tissue cells do not adhere to polystyrene Petri dishes, but adhere well to glass or tissue culture dishes (cf. Martin \& Rubin, 1974). The adhesion of many tissue cells to unsuitable surfaces, e.g. polystyrene Petri dishes, may be increased through the addition of serum proteins, which adsorb on to the substratum surface (Weiss, I959 $a, b$; Rappaport, Poole \& Rappaport, I960; Martin \& Rubin, I974), whereas adhesion to suitable surfaces may be retarded by adsorbed protein (Taylor, 196I; Maroudas, $1975 a$ ).

The importance of surface charge was considered in the tissue culture dish experiments (Table 2). Tissue culture dishes have a higher surface charge density than Petri dishes $\left(5.6 \times 10^{-4}\right.$ and $3.3 \times 10^{-4} \mathrm{~N} \mathrm{~cm}^{-1}$, respectively; Maroudas, 1973), and the number of bacteria attached to them was accordingly lower (Fletcher, unpublished). Adsorption of a protein with a suitable isoelectric point might neutralize the high surface charge density of the tissue culture dish and thereby increase the number of bacteria able to attach. However, gelatin and pepsin further reduced attachment to tissue culture dishes and protamine had no effect - results which correspond to attachment on protein-coated Petri dishes (Table I). Since the surface charge density of the attachment surface had no effect on the ability of adsorbed proteins to interfere with attachment, protein films probably inhibit attachment through non-electrostatic repulsion mechanisms, such as steric exclusion (Hesselink, Vrij \& Overbeek, I97I ; Maroudas, I975a,b).

The lack of attachment inhibition with the basic proteins protamine and histone (Table I) probably resulted from their not being adsorbed on to the polystyrene (see Protein treatments iii, in Methods). However, it is possible that the bacteria could attach to polystyrene coated with basic proteins but not to neutral or acidic protein-coated polystyrene.

The results reported here differ from those of Meadows (197I), who found that albumin and salmine (protamine) inhibited adhesion to glass, whereas casein and gelatin facilitated it. This disparity is not really surprising, since Meadows used different bacterial strains and a different attachment surface from those used here.

I am very grateful to Dr G. 1. Loeb, United States Naval Research Laboratory, for many stimulating discussions and for helpful advice. 


\section{REFERENCES}

Brooks, D. E. \& Seamann, G. V. F. (1973). Effect of neutral polymers on the electrokinetic potential of cells and other charged particles. Journal of Colloid and Interface Science 43, 670-686.

CORPE, W. A. (1970). Attachment of marine bacteria to solid surfaces. In Adhesion in Biological Systems pp. 73-87. Edited by R. S. Manly. New York and London: Academic Press.

Curtis, A. S. G. (1962). Cell contact and adhesion. Biological Reviews 37, 82-1 29.

Fletcher, M. (1974). Microbial attachment: the adhesion of bacteria to solid surfaces. Ph.D. thesis, University College of North Wales.

Fletcher, M. \& Floodgate, G. D. (1973). An electron-microscopic demonstration of an acidic polysaccharide involved in the adhesion of a marine bactelium to solid surfaces. Journal of General Microbiology 74, 325-334.

Florkin, M. \& Stotz, E. H. (1963). Comprehensive Biochemistry, vol. 7. Amsterdam, London and New York: Elsevier.

Fruton, J. S. \& Simmonds, S. (1958). General Biochemistry, 2nd edn. London: Chapman \& Hall.

Hesselink, F. Th., VRIJ, A. \& Overbeek, J. Th. G. (1971). On the theory of the stabilization of dispersions by adsorbed macromolecules. II. Interaction between two flat particles. Journal of Physical Chemistry 75, 2094-2103.

Heukelekian, H. \& Heller, A. (1940). Relation between food concentration and surface for bacterial growth. Journal of Bacteriology 40, 547-558.

Hugh, R. \& LEIFSON, E. (1953). The taxonomic significance of fermentative versus oxidative metabolism of carbohydrates by various Gram-negative bacteria. Journal of Bacteriology 66, 24-26.

KING, E. O., WARD, M. K. \& RANEY, D. E. (1954). Two media for the demonstration of pyocyanin and fluorescin. Journal of Laboratory and Clinical Medicine 44, 301.

Kovícs, N. (1956). Identification of Pseudomonas pyocyanea by the oxidase reaction. Nature, London $\mathbf{r 7 8}^{8}$, 703 .

LLoyd, B. (1937). Bacteria in stored sea water. Journal of the Royal Technical College, Glasgow 4, $173-177$.

Maroudas, N. G. (1973). Chemical and mechanical requirements for fibroblast adhesion. Nature, London 244, 353-354.

Maroudas, N. G. (1975a). Adhesion and spreading of cells on charged surfaces. Journal of Theoretical Biology 49, 417-424.

Maroudas, N. G. (1975b). Polymer exclusion, cell adhesion and membrane fusion. Nature, London 254, $695-696$.

Marshall, K. C., Stout, R. \& Mrtchell, R. (1971). Mechanism of the initial events in the sorption of marine bacteria to surfaces. Journal of General Microbiology 68, 337-348.

Martin, G. R. \& RubiN, H. (1974). Effects of cell adhesion to the substratum on the growth of chick embryo fibroblasts. Experimental Cell Research 85, 319-333.

Meadows, P. S. (1971). The attachment of bacteria to solid surfaces. Archiv für Mikrobiologie 75, 374-38I.

NeWMaN, H. N. (1974). Microbial films in nature. Microbios 9, 247-257.

RAPPAPORT, C., PoOle, J. P. \& RAPPaPORT, H. P. (1960). Studies on properties of surfaces required for growth of mammalian cells in synthetic medium. I. The HeLa cell. Experimental Cell Research 20, 465-510.

Shewan, J. M., Hobbs, G. \& Hodgkiss, W. (1960). A determinative scheme for the identification of certain genera of Gram-negative bacteria, with special reference to the Pseudomonadaceae. Journal of Applied Bacteriology 23, 379-390.

TAYLOR, A. C. (1961). Attachment and spreading of cells in culture. Experimental Cell Research, s 8, I 54-173.

Weiss, L. (1959a). Studies on cellular adhesion in tissue culture. I. The effect of serum. Experimental Cell Research 17, 499-507.

WEISS, L. (1959b). Studies on cellular adhesion in tissue culture. II. The adhesion of cells to gel surfaces. Experimental Cell Research 17, 508-515.

WeIss, L. (1964). Cellular locomotive pressure in relation to initial cell contacts. Journal of Theoretical Biology 6, 275-28I.

ZoBell, C. E. (1943). The effect of solid surfaces upon bacterial activity. Journal of Bacteriology 46, 39-56.

ZoBell, C. E. \& ANDERSON, D. Q. (1936). Observations on the multiplication of bacteria in different volumes of stored seawater and the influence of oxygen tension and solid surfaces. Biological Bulletin 7r, 324-342. 